\title{
MAURO ZONTA \\ AND THE UNITY OF MEDIEVAL PHILOSOPHY
}

\author{
JOHN MARENBON \\ UNIVERSITY OF CAMBRIDGE
}

I never met Mauro Zonta. From his publications-not only their number, but their character: every page full of new information and new discoveries-I thought he must be an old man, and I pictured him with a white beard. I was right about the beard, but not the age. When he died in August 2017, Mauro Zonta was just short of 50: not just a sad loss to scholarship, and to his family and friends, but a tragically premature one.

I am writing, not from the position of a colleague of Zonta's in Jewish philosophy, or of an expert on medieval translation movements, but from the perspective of a generalist-as someone who has a wide interest in medieval philosophy in all its varieties and tries to make a wider public aware of this rich subject. And from my perspective Zonta's work looms especially large. Why?

To oversimplify (as a generalist is inclined to), if the most important innovation in studying medieval philosophy at the end of the twentieth century was the influence of contemporary analytic work, over the last two decades the most important development has been the move towards full recognition of philosophy written in Greek, Arabic and Hebrew as integral parts of medieval philosophy, along with the Latin sub-tradition rather than subordinated to it. Of course, there have been experts in Byzantine, Islamic and Jewish philosophy for centuries, but they have tended to see these sub-traditions only in terms of what they brought to Latin philosophy, or else they have studied one of them in isolation. For the most part, this new development so far has consisted in bringing to the awareness of all who work on medieval philosophy the importance and intellectual value of specifically Islamic, Jewish and Byzantine features and texts, which never reached the Latin world-most strikingly the great philosophers in the broad Avicennian tradition. A problem, however, with this approach is that it highlights the separateness of the sub-traditions rather than their interrelations. 
Zonta, however, has shown-what might never have become clear without his scholarship and his particular angle of approach to reveal it-that medieval Jewish philosophy written in Hebrew in Christian Europe provides the best defence against the danger of untwining the multifaith and plurilinguistic thread of medieval philosophy. In the first of the two works of his most important to the more general reader, La filosofia antica nel Medioevo ebraico (1996), Zonta looks at the philosophical translation movement into Hebrew from the thirteenth to the fifteenth century. In doing so, he considers a phenomenon which, although it is parallel to translation movements into Arabic, Greek and Latin, was specific to the Jewish world, and he treats it so as fully to explore its specificity, examining not merely the techniques of the translators, but their aims and how they justified their activity within their own communities. But Zonta also shows how this specifically Jewish phenomenon involves the other sub-traditions of medieval philosophy. The book's title is far narrower than its real scope, since Zonta considers not only translations of ancient Greek texts and commentaries, but translations of Arabic commentaries and compendia, and of Latin commentaries.

These translations, of Latin scholastic writing into Hebrew, are the thread that links this book to the one Zonta published ten years later, Hebrew Scholasticism in the Fifteenth Century. Here Zonta identifies a group of fifteenth-century Jewish philosophers in Italy, Provence and the Iberian Peninsula who were familiar with Latin scholastic texts and used them as the basis for their own philosophizing in the same style. The book is a model of clear and informative presentation, offering both a history of this movement and translated summaries of some of the most important texts, making available to any interested reader material previously hidden away in Hebrew manuscripts. Even more than La filosofia antica, it at once illuminates what is particular to Jewish philosophy and, at the same time, how the different sub-traditions, not just Islamic and Jewish, but Christian Latin too, reacted on one another. In their quiet way, these two books and much of Zonta's other work have contributed enormously to understanding, not just the richness and variety of medieval Jewish thought, but the multi-stranded unity of the whole medieval philosophical tradition. 